said that the Department of Scientific and Industrial Research has started a comprehensive collection of translations of Russian scientific and technological literature in all fields, except clinical medicine. This material is being made available through the Department's Lending Library Unit, which also lends Russian technical literature to research organizations, industrial organizations, universities and colleges and Government departments. Microfilms of several thousand translations of Russian scientific papers have also been ordered from a library in the United States. In conjunction with the Scientific Library and Technical Information Committeo of the Advisory Council on Scientific Policy, the Department is considering what additional measures are required to improve the volume of translations of Russian scientific papers and books being undertaken in the English-speaking world.

In answer to further quostions, Mr. Nicholls said that the Department has undertaken to consider proposals for contracts dosigned to promote developments of particular ideas or in particular industries, in the public interest, when these are outside the scope of, or unacceptable to, the National Research Development Corporation. The suggestion in the last annual report of the Advisory Council on Sciontific Policy that British firms might make arrangements to interview British scientists and ongineers in North America has been referred for consideration to tho appropriate committees of the Federation of British Industries, and the Department of Scientific and Industrial Research is considering what action could be taken to encourage more British scientists and engineers to undertake postgraduate work in Europe.

\section{Progress in Technical Education}

ANswering questions in the House of Commons about technical education on November 28, Mr. Geoffrey Lloyd, Minister of Education, said that since the publication of the White Paper in February 1956, eighteen new technical colleges and seventy-nine major extensions of existing colleges have been started. In addition, final plans for five more new colleges and seventeon further major extensions with a total value of $£ 5$ million have been approved, and sketch plans prepared for a further fourteen now colleges and twenty-eight major extensions, to the value of more than $f 8$ million. There were 31,700 part-time day students of higher technology in Britain in 1955-56.

\section{Nigerian Geographical Journal}

IT is a sign of geographical progress that the goography of regions that were literally being explored by Europoans only two or three gonerations since is now being written from the inside. Europeans and Americans may still write books ontitled "Africa" and they will still have value because of their external and comparative points of view. But a day must come when the geography of Africa is written from within, and of that day the first number of the Nigerian Geographacal Journal is a harbinger (1, No. 1; April 1957. Pp. iv +20 . Per volume of two numbers, 15s. Ibadan: University Colloge, 1957). Its first function is to be a means of communication, giving the members of the two-year-old Nigerian Goographical Association-still fewer than a hundred all told and scatterod over a vast territory-a sense of community and common endeavour. Its second is to afford a means of self-exprossion for Nigerian geography. Of the articles in this issue the first is, understandably enough, the text of an address given by Prof. B. J Garnier, of the Department of Geography, University College, Ibadan, to the members of the Assc ciation on the importance of their subject. Another, by a Nigerian teacher in a Government secondary school, says some homely and helpful things about geography teaching to his fellow-teachers. Of more interest and significance, however, are two articles that doscribe parts of Nigeria. The longer and more sophisticated of these is from the sympathetic pen of the viceprincipal of the Government Teachor Training College, Ibadan; the shorter is a description of his home district by a Nigerian undergraduate. Hore is the beginning of an African geography written by those who alone can truly understand tho human eloment in the man-land equation in Africa.

\section{British Museum (Natural History)}

Among the more important recent acquisitions to tho British Museum (Natural History) is a gift by Mrs. P. Harwood of the very fine collection of British insects amassed by the late Philip Harwood, formerly of Kineraig, Inverness-shire, and latterly of Wimborne, Dorset, during a life-time devoted to spocialized collecting. In addition to his own collecting there are many specimens from the colloctions of his father and his brother. It was Mr. Harwood's special wish that the Hymenoptera and the Homiptera should go to the British Museum and the remainder to the University Museum, Oxford. The collection has not yot been counted, but it is estimated that it contains many thousands of specimens, including some of very rare and valuable spocies which will fill long-vacant gaps in the Museum's collections, and many individuals on which were based the first rocords of the occurrence in the British Isles of the species concerned.

\section{The Botanic Gardens, Singapore}

$A_{N}$ encouraging account of the work done at the Botanic Gardens, Singapore, during 1956 has been prepared by the former director, J. W. Purseglove. Besides the usual meteorological rocords and the extensive activities connected with the herbarium, the staff mado many contributions to botanical knowledge through collections and research. One marine green alga, collected at Mersing, was found to be A celabularic crenulata, a new record for Malaysia. Considerable horticultural work was also carried out despite dopredations by monkeys and human beings. The former learned to respect the olectric fence which was put up around the orchid enclosure; but this did not prevont intrusions by human beings. As a result of thefts it is no longer possible to display valuable orchids in the plant house. The staff continued to advise many schools and other government institutions during the year. Copies of this interesting report may be obtained from the Government Publications Bureau, G.P.O., Fullerton Buildings, Singapore, prico 1.50 dollars.

\section{Root Nodules of Casuarina}

G. Bowd has reported that young plants of Casuarina cunninghamiana and $C$. equisetifolia, growing in water culture, developed macroscopic nodules in 26-35 days from inoculation, the nodula. tion being most successful at $p \mathrm{H}$ near neutrality and falling off much more rapidly at lower $p \mathrm{H}$ than 